\begin{tabular}{|c|c|c|c|}
\hline Eiszeitalter u. Gegenwart & $\mathbf{4 8}$ & $162-169$ & Hannover 1998 \\
\hline
\end{tabular}

\title{
Preliminary report on the middle Pleistocene small mammal fauna from Yarimburgaz Cave in Turkish Thrace
}

\author{
Winfried SANTEL \& WigharT VON KOENIGSWALD*) \\ - small mammels, middle Pleistocene, Turkey, Turkisch Trace, Yarimburgaz Cave, pellets -
}

\begin{abstract}
From cave sediments of Yarimburgaz Cave in Turkish Trace two faunal assemblages are described. In addition to taxa present in the area today the limited fauna of the older Cycle I contains only Cricetus cricetus. The Cycle III produced a much richer fauna and contained most of the archeological material excavated form this cave. The fauna is characterized by immigrants from the steppe environments of the Russian plains (Lagurus transiens/lagurus, Cricetus cricetus, Ochotona pusilla, and Sicista subtilis) as well as from the south (Rattus rattus). Ecologically the occurrence of these species indicates a wide extension of the steppic area to the south. Although Arvicola cannot be used as a stratigraphic indicator in the Mediterranean area, the intermediate type of the chronospecies Lagurus transiens and L. lagurus indicate a middle Pleistocene age.
\end{abstract}

\section{[Vorbericht über die mittelpleistozäne Kleinsäugerfauna aus der Yarimburgaz-Höhle in Türkisch Thrazien]}

Zusammenfassung Aus den Ablagerungen der Yarimburgaz-Höhle werden zwei Kleinsäugerfaunen vorgelegt. Die sehr begrenzte Fauna aus dem älteren Sedimentationszyklus I enthält außer Arten, die auch heute noch in der weiteren Region verbreitet sind, vor allem Cricetus cricetus. Die jüngere Fauna aus dem Zyklus III, der einen großen Teil des archäologischen Materials geliefert hat, ist auch faunistisch erheblich reicher. Die Fauna ist gekennzeichnet durch Einwanderer aus dem südrussichen Steppengürtel (Lagurus transiens/lagurus, Cricetus cricetus, Ochotona pusilla, und Sicista subtilis). Hinzu kommt Rattus rattus als Einwanderer von Süden. Die ökologische Interpretation läßt auf eine erhebliche Ausweitung der Steppenregion nach Süden schließen. Arvicola ist im Mittelmeerraum als stratigraphischer Indikator nicht brauchbar. Dagegen kann aus der Übergangsform von Lagurus transiens zu L. lagurus ein mittelpleistozänes Alter abgeleitet werden. Dabei kann das frühere wie das spätere Mittelpleistozän ausgeschlossen werden.

\section{Introduction}

Yarimburgaz Cave is located in the Bosporus area $25 \mathrm{~km}$ west of Istanbul in Turkish Thrace. The cave has been known since last century, but the

\footnotetext{
* Anschriften der Verfasser: Dipl.-Geol. W. Santel, Prof. Dr. W. v. Koenigswald, Institut für Paläontologie der Universität Bonn, Nussallee 8, D-53115 Bonn,
}

main scientific excavations were carried out by C. Howell and M. ARSEBÜK from 1988 to 1990. The small mammals from their excavations were initially investigated by W. v. K. (Koenigswald 1989) and than in more detail by W. S: (SANTEL in press). The large mammals are under study by C. HowelL, M.C. Stiner and E. Tsoucala (STINER et al. 1996, 1998).

The two chambers of the cave contain sediments from the Lower and Middle Pleistocene. The cave was used until Byzantine times. The excavations were carried out in various squares $(P, S, T, V, R$, and $\mathrm{U}$ ) in different parts of the cave. The stratigraphic sequences in the various squares could be correlated with each other except for square U. According to the sedimentological investigation of W. FARRAND (1989, and pers. comm. 1990, 1993), nine layers can be distinguished which belong to three different sedimentation cycles (cycle I, II and III). For the interpretation of the small mammal fauna square $\mathrm{U}$ is of greatest interest since the layer $\mathrm{U}-1$ produced the majority of the small mammal specimens (about 80\%). Even though the sediments of square $\mathrm{U}$ cannot be correlated with the stratigraphy of the other squares, the layer U-1 clearly belongs to the youngest, sedimentation cycle III (Howell \& ARSEBÜK 1989). Therefore most information derived from the small mammal fauna refers to the time of third sedimentation cycle only.

Two taphonomic factors led to the concentration of small mammals in Yarimburgaz Cave. Most of the small mammal remains were concentrated by owls dropping pellets at their roosting sites. Even though investigations of recent pellet accumulation document quantitative biases in such accumulations due to individual preferences of specific owls, their qualitative composition yields significant data for a paleoecological and stratigraphical analyses. We are aware that some difficult to catch species, like the spiny hedgehog (Erinace$u s$ ), are often missing in pellets of smaller owls. Such biases can be tolerated, however only, if faunas from pellets are compared to each other. 
The second taphonomic process accumulating small mammals in Yarimburgaz Cave only acts on bats. The taxa Myotis myotis, M. blythi, Rbinolophus ferrumequinum, $R$. mehelyi, and Miniopterus schreibersi were identified so far. Attritional mortality leads to carcass accumulation and burial because the bats used the cave for hibernation. The bat fauna could not be interpreted in this paper.

\section{The small mammal fauna}

The following taxa were identified from Yarimburgaz Cave from the lower cycle I and the upper Cycle III. The letters $\mathrm{U}-1, \mathrm{X}, \mathrm{W}$, etc. indicate the layers.

\section{Soricidae}

\section{LIPOTYPHLA}

Crocidura suaveolens (PALLAS, 1811) vel leucodon (Hermann, 1780)

Cycle III: U-1

Sorex $\mathrm{cf}$. raddei SATUNIN, 1895

Cycle III: strata unidentified (X, W, or V), not present in extant fauna

\section{Talpidae}

Talpa levantis Thomas, 1906 Cycle III: U-1

\section{RODENTIA}

\section{Sciuridae}

Spermophilus cf. citellus (LinNAEus, 1766)

Cycle III: X and W

\section{Myoxidae}

Myomimus roachi (BATE, 1937)

Cycle III: U-1

\section{Muridae}

\section{Murinae}

Apodemus (Sylvaemus) sylvaticus (Linnaeus, 1758)

Cycle III: U-1, X

Apodemus sp.

Cycle I: S

Apodemus mystacinus (DANFORD \& ALSTON, 1877)

Cycle I: S, not present in extant fauna Rattus rattus (LINNAEus, 1758)

Cycle III: W, see comment below.

\section{Cricetinae}

Cricetus cricetus (LiNNAEUs, 1758)

Cycle I: S; Cycle III: X, W; not present in extant fauna

Mesocricetus cf. newtoni (NeHRING, 1898)

Cycle III: U-1, X, and W, not present in extant fauna
Cricetulus migratorius (PALLAS, 1773)

Cycle I: S; Cycle III: U-1, X, W

\section{Arvicolinae}

Arvicola terrestris (LinnaEus, 1758)

Cycle III: X and W, see comment below.

Microtus arvalis (PALLAS 1778)

Cycle III: U-1, X and W

Microtus guentheri DANFORD \& ALSTON, 1880

Cycle III: U-1, X and W

Microtus (Terricola) sp.

Cycle III: U-1, X, and W; Cycle I: S

Clethrionomys glareolus (SCHREBER, 1780)

Cycle III: U-1 and X, not present in extant

fauna.

Lagums transiens/lagurus

Cycle III: U-1, not present in extant fauna, see comment below.

\section{Spalacinae}

Nannospalax cf. leucodon Nordmann, 1840

Cycle I: S; Cycle III: U-1, X and W

\section{Dipodidae}

Sicista subtilis (PALlas, 1773)

stratum not identified, possibly U-1, not present in extant fauna

\section{LAGOMORPHA}

Ochotona pusilla (PALlas, 1769)

Cycle III: U-1 and W, not present in extant fauna, see comment below.

Lepus sp.

Cycle I: S; Cycle III: U-1

cf. Oryctolagus cuniculus (LinNAEUs, 1758)

Cycle III: W, not present in extant fauna

A detailed description of all taxa mentioned is given in another paper (SANTEL in press).

\section{Paleogeographical reconstruction of Cycle I}

All small mammals from cycle I come from layer

S. The fauna consists of:

Apodemus mystacinus

Apodemus sp.
Cricetus cricetus
Cricetulus migratorius
Microtus (Terricola) sp.
Nannospalax cf. leucodon
Lepus sp.

Most species of this assemblage occur in the extant fauna of the general region. Apodemus mystacinus occurs only on the eastern side of the Bosporus and on the Balkan peninsula. Cricetus cricetus is the only species indicating a somewhat more continental and drier environment for layer $S$ in Yarimburgaz Cave since its nearest present 
day occurrence is in the Russian plains north of the $44^{\circ}$.

A detailed stratigraphical assignment can not be given for this faunal assemblage. Its composition indicates a Middle or Upper Pleistocene age because of Cricetus cricetus and Cricetulus migratorius.

\section{Paleogeographical reconstruction of Cycle III}

No identifiable small mammals are available from cycle II. The stratigraphically younger cycle III yielded the major part of the faunal remains. Most of the archeological material belongs to this sedimentation cycle as well (HOWELL \& ARSEBÜK 1989). Most specimen come from Level U-1. Sedimentological analysis indicates that cycle III was deposited in an relatively short period of time (FARRAND pers. comm. 1993). The following species are present.

Crocidura suaveolens vel leucodon

Sorex cf. raddei

Talpa levantis

Spermophilus cf. citellus

Myomimus roachi

Apodemus (Sylvaemus) sylvaticus

Rattus rattus

Cricetus cricetus

Mesocricetus cf. newtoni

Cricetulus migratorius

Arvicola terrestris

Microtus arvalis

Microtus guentheri

Microtus (Terricola) sp.

Cletbrionomys glareolus

Lagurus transiens/lagurus

Nannospalax cf. leucodon

Sicista subtilis

Ochotona pusilla

Lepus sp.

cf. Oryctolagus cuniculus

Even if the fauna contains species characteristic of different environments such as steppe, dry and open country, open landscape with bushes and some trees (NiETHAMmer \& Krapp 1978, 1982, 1990), a similar mixture of species is found today in Turkish Thrace. However, the percentage of steppic elements is distinctly higher in cycle III of Yarimburgaz Cave, indicating a landscape more open and dryer than today. In particular the greater steppic influence is indicated by taxa not present in the area any more: Cricetus, Mesocricetus, Cricetulus, Lagurus, Sicista subtilis, and Ochotona pusilla. Most of these species are characteristic for the Ukraine and the Russian plains north of Turkish Thrace. Although the steppic species occur even in semi-deserts, other species such as Sorex, Apodemus sylvaticus and Cletbrionomys glareolus signalize the presence of at least restricted areas with denser vegetation. In contrast to the many immigrants from the north, Rattus rattus definitely immigrated from the south, most probably from the Levant where the earliest Rattus is found in Oumm Quatafa (TCHERNOv 1994). Because of the wide range of Rattus, this genus seems not to be a good ecological indicator. In Central Europe, especially Lagurus and Ochotona are regarded as indicators for cool and dry climatic conditions (Heinrich 1983, Sutcliffe \& KowalSKI 1976). Among the soricids Sorex reaches farthest north. Crocidura leucodon and/or suavolens are more sensitive to cold climates and are absent during glacial periods in Central Europe. The presence of these taxa and of Mediterranean species like Myomimus roachi provide the lower temperature limit for the cycle III fauna. The southern shift of the steppic area to the Bosporus region as documented by the fauna of cycle III most probably was caused by a general temperature decrease and a reduction of rainfall. A cold phase with such a significant ecological shifts most probably reflects a glacial period.

One of the voles probably is traditionally described as Microtus rossiaemeridionalis. The difference of the extant taxon was based on karyological characters. Therefore it can not be examined in the fossil material. Since we want not to indicate the antiquity of the karyotype modification we use the traditional term based on morphological characters.

\section{Stratigraphically significant taxa of cycle III}

In addition to the ecologically informative species the fauna of cycle III contains some species often used for stratigraphic purposes. These are Arvicola terrestris, Lagurus transiens/lagurus, Ochotona pusilla, and Rattus rattus.

\section{Arvicola terrestris (Fig. 1a)}

In Arvicola specimens form Central Europe, the relative thickness of the enamel band in leading and trailing edges of the dentin triangles was used as a stratigraphic indicator (KoENigswald 1973, HeInRICH 1982, 1987). The more primitive situation with a thick trailing edge was regarded to characterize the Middle Pleistocene Arvicola cantianus, while the Upper Pleistocene Arvicola terrestris shows a significant reduction of the thickness 
of trailing edge. In the Mediterranean, especially in Spain and Turkey, the underived condition is still present in the extant fauna (ROETTGER 1987). The Spanish form is identified as Arvicola sapidus (Miller 1908), the Turkish one as Arvicola terrestris persicus (De Filippi, 1865).

Arvicola from Yarimburgaz Cave, represented by 7 molars, shows thickened trailing edges like $A$.

\section{Lagurus transiens/lagurus (Fig. 2)}

Molars of Lagurus, the gray lemming, are characterized by the lack of cementum and the typical dentine tract in the anterior lobe. Two species, the Middle Pleistocene $L$. transiens and the extant $L$. lagurus, have to be considered in the identification of the fossil material of Yarimburgaz consisting of eight lower M.. The length of the M. (2,35-2,58
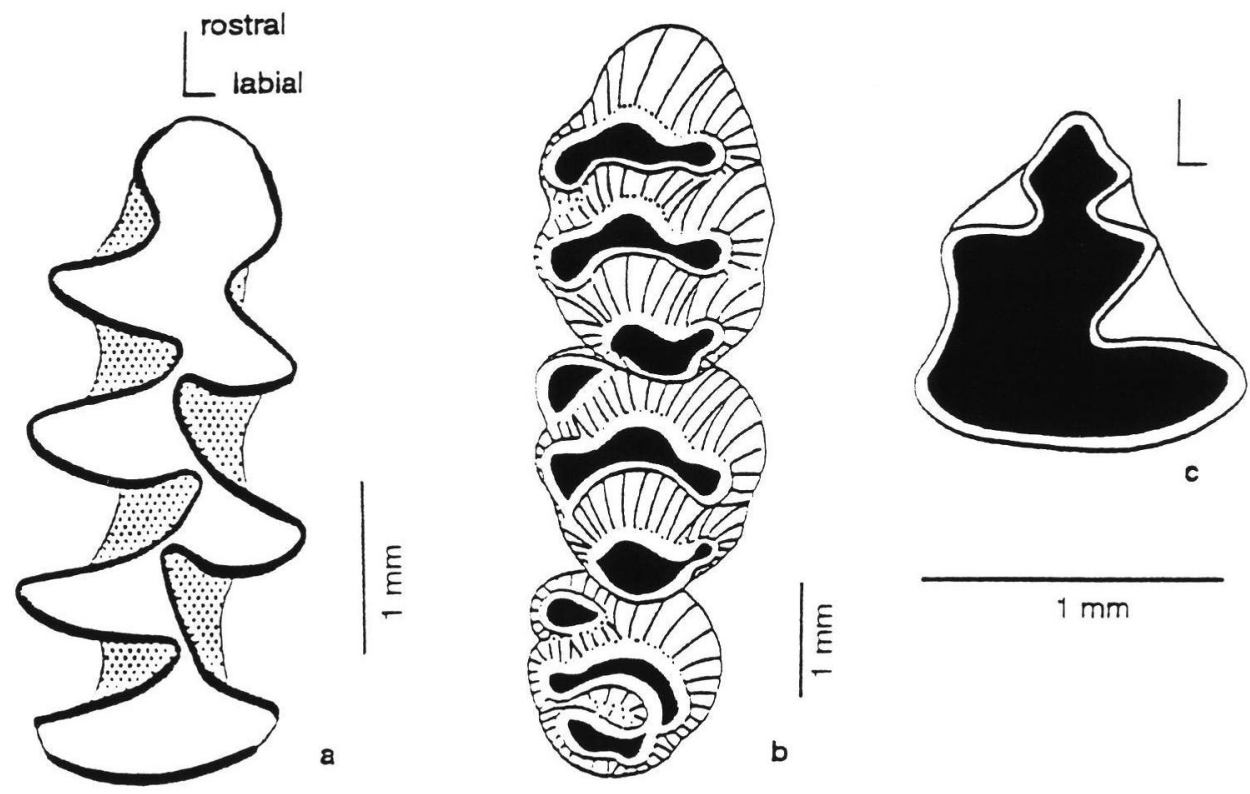

Fig. 1a: Arvicola terrestris, first lower molar, level U-1, (YSM 22).

Fig. 1b: Rattus rattus, left maxilla with M1-3, layer W, (YZM 11).

Fig. 1c: Ochotona pusilla, left lower P3 (drawn from below), level U-1, (YSM 62).

All specimen come from the the Middle Pleistocene of Yarimburgaz Cave, sedimentation cycle III, Turkish Thrace.

Abb. 1a: Arvicola terrestris, erster unterer Molar, Fundhorizont U-1, (YSM 22).

Abb. 1b: Rattus rattus, linke Oberkieferhälfte mit M1-3, Schicht W, (YZM 11).

Abb. 1c: Ochotona pusilla, linker unterer P3 (von unten gezeichnet), Horizont U-1, (YSM 62).

Alle Stücke stammen aus dem Mittelpleistozän der Yarimburgaz-Höhle, Sedimentationszyklus II; Türkisch Thrazien.

cantianus but in the Mediterranean this character obviously cannot be used in age assignments. Neither can the absence of the primitive $M i$ momys-fold in two lower M1 (length 3,84 and $3,77 \mathrm{~mm}$ ), be used as a stratigraphic indicator, since this trait is rare in $A$. cantianus. In Turkey it is difficult to distinguish between $A$. cantianus and A. terrestris. As Kolfschoten $(1988,1990)$ accepts both taxa as subspecies of $A$. terrestris only the Yarimburgaz Arvicola is not identified in more detail.

Since the genus name Arvicola is male the ending of the species name has to be male too therefore Arvicola cantianus is the valid form. mm with a mean of 2,45) is intermediate between both species if measurements from Central Europe are used (Chaline 1972, Heinrich 1990, Janossy 1962). Lagurus lagurus form Chios described by STORCH (1975) is slightly larger than the Yarimburgaz material. The morphology of the anterior lobe can be studied is seven M.. Two of them (Fig. $2 \mathrm{a}-\mathrm{b})$ fall into the range of variability of Lagurus lagurus, but four show the pattern typical of $\mathrm{La}$ gurus transiens (Fig. 2 e-h), characterized by the missing or fairly slight reentrant folds of the cap of the anterior lobe.

If the material that exclusively came from level U1 , is regarded as representative, the Yarimburgaz 

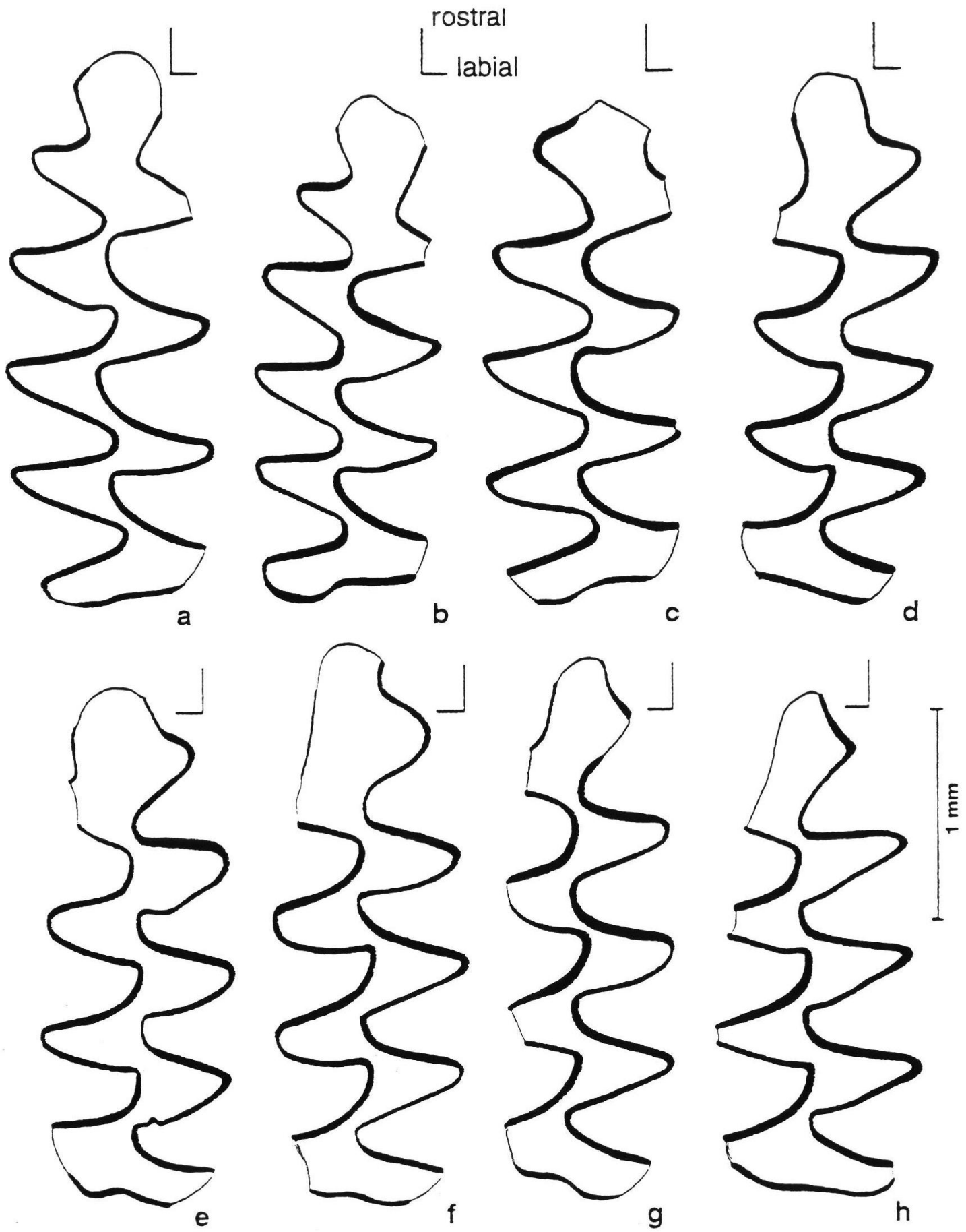

Fig. 2: Lagurus transiens/lagurus, transitional from. Occlusal surfaces of lower first molars indicating the morphological variability. Middle Pleistocene of Yarimburgaz Cave, sedimentation cycle III, Turkish Thrace.

Abb. 2: Lagurus transiens/lagurus, intermediäre Form. Kauoberflächen des jeweiils ersten unteren Molars zeigen die morphologische Variabilität. Mittelpleistozän der Yarimburgaz-Höhle, Sedimentationszyklus III; Türkisch Thrazien. 
population most likely was transitional between both species.

\section{Rattus rattus (Fig. 1b)}

A left upper maxilla with all molars in place morphologically matches Rattus rattus so well that an identification is beyond questioning. It differs from Rattus norvegicus in several morphological characters of the M. Although the measurements of the molars fall into the range of extant Rattus rattus from western Anatolia (FELTEN et al. 1971), contermination by recent material is not probable, since the maxilla is well fossilized like all other bones from layer W. Rattus is rare in the Mediterranean Middle Pleistocene and missing in Central Europe. Rattus haasi was described from Qumm Qatafa in Israel (TCHernov 1968). However, as it is represented by lower molars only it is difficult to compare with our material. STORCH (1975) attributes upper and lower molars from Chios to Rattus rattus. These teeth are somewhat larger than the Yarimburgaz material but are still in the range of $\mathrm{R}$. rattus in Anatolia.

\section{Ochotona pusilla (Fig. 1c)}

This small lagomorph is represented by several isolated molars, one P3, and 7 mandibular fragments. The species $O$. pusilla can be identified by the morphology of the lower P3, especially by the deep lingual reentrant fold separating an enlarged posterior part from the medial part and by the rhomboid shape of the anterior part (Fig. 1c). This shape is known in O. pusilla from the Middle Pleistocene from Central Europe, from Stránská Skála (ToBIEN 1972) and Hunas (Heller et al. 1983). The length of the alveolar tooth row in the lower jaw is very similar in Middle and Upper Pleistocene material attributed to O. pusilla.

Ochotona is known in the Mediterranean Middle Pleistocene in Central Anatolia (Monture et al 1994) and from Qumm Qatafa in Israel (TCHERNOV 1994) but is missing in Chios (STORCH 1975). Ochotona pusilla which occurs today in the Russian plains, did not reach the Eastern Mediterranean during the cold periods of the Late Pleistocene.

\section{Age Assignment}

The stratigraphic position of the cycle III of Yarimburgaz Cave is marked best by the transition of Lagurus transiens to L. lagurus in level U-1. In the Ukraine and in the plains of southern Russia, the transition between L. transiens and L. lagurus Occurs in the Gungki-Complex, containing the Oka-
Glacial and the Likhvin interglacial period of the Middle Pleistocene (Markova 1990, 1992). The lower Middle Pleistocene starting at the BrunhesMatuyama boundary can be excluded because at this time Mimomys savini is still present. Arvicola occurs only in the latest interglacial periods of the Cromerian complex. The upper part of the Middle Pleistocene in Russia is characterized by the presence of the derived Lagurus lagurus. In Yarimburgaz Cave cycle III, level U-1, documents the transition from Lagurus transiens to L. lagurus. Therefore the fauna allows to narrow down the age of cycle III in Yarimburgaz Cave to a cold period in the middle of the Middle Pleistocene. The relative stratigraphic position of Yarimburgaz Cave to some Middle Pleistocene localities of the region is of biogeographic interest.

The fissure filling of Emirkaya-2 near Seidisehr in Central Anatolia was recently published on by Monture et al. (1994). The fauna seems to be definitely older than Yarimburgaz Cave cycle III if the molar of Mimomys savini belongs to this assemblage. Among the many species this fauna shares with the Yarimburgaz Cave cycle III fauna, Ochotona and three cricetine species are of significance. As an additional element of the steppe environment Allactaga occurs in the Anatolian fauna. Therefore the ecological interpretation of Emirkaya-2 as representing an open and humid environment with a forest in the vicinity has to be questioned. The stratigraphic assignment of this fauna to the Holsteinian, corresponding to the Mindel-Riss interglacial period, cannot be used as a stratigraphic marker since at the time being no vertebrate fauna in Central Europe can be attributed with certainty to the Holsteinian. Even the Holsteinian of northern Germany can not be correlated with sufficiency to the glacial sequence of the Alpine region (KoENIGSWALD 1992).

From the Aegean Island of Chios, which was part of the mainland during the Middle Pleistocene, STORCH (1975) described a fauna from the fissure filling Latomi-1. It is assumed to be not older than the middle part of the Middle Pleistocene. STORCH (1975) attributes the Arvicola material from Chios to $A$. praeceptor which is regarded as a younger synonym of Arvicola cantianus (KoENIGSWALD 1973). In the thickness of the enamel band, the trailing edges surpass the leading edges, as is typical for a. cantianus in Central Europe. As discussed above, this character is of little significance in the Mediterranean. Therfore we do not consider the identification of $A$. cantianus at Chios to indicate that this fauna may be older than the cy- 
cle III fauna from Yarimburgaz Cave. Lagurus offers a better correlation. STORCH (1975) identified Lagurus lagurus in the fauna of Chios, which is more derived than the transitional form found at Yarimburgaz Cave. Therfore we argue that the Chios fauna is somewhat younger than the fauna of cycle III in Yarimburgaz Cave. Form Israel, TChernov (1968, 1994) described a fauna from Qumm Qatafa in the Judean desert near Bethlehem. So far no distinct stratigraphic position is known for Qumm Qatafa. It is difficult to compare this fauna with Yarimburgaz Cave since it is situated almost $10^{\circ}$ further south. The Israeli fauna contains several African elements. Nevertheless, it shares two important taxa with the fauna of Yarimburgaz Cave. These are Ochotona as a northern immigrant and Rattus as an immigrant from the southeast. On the other hand, instead of the cricetines present in Yarimburgaz Cave, in Qumm Qatafa more primitive cricetines occur. The species at Yarimburgaz Cave occur in Israel much later, for instance in Hayonim (TCHERNov 1994). This may suggest that the fauna of Qumm Qatafa is older than the cycle III from Yarimburgaz Cave, even if such a correlation bears great uncertainties.

\section{Biogeographical implications}

Even if Yarimburgaz Cave occupies a very marginal position in Europe, the occurrence of several taxa predates the estimated immigration time into this continent, as given by Hosey (1982). While Mimomys roachi, Apodemus mystacinus, Microtus guentheri, and Mesocrietus were assumed to have crossed the Bosporus at the lowest sea level stand during the last glaciation, the finds from Yarimburgaz Cave prove that these species were present west of the Bosporus much earlier. The occurrence of Talpa levantis in the Middle Pleistocene of Yarimburgaz Cave may strengthen the idea of VoHralik (1991), who postulated that T. levantis originated in Asia Minor and penetrated the Balkan region. The small number of Middle Pleistocene localities neither permits the identification of the route of immigration nor of the exact time. Because of the several climatic oscillations combined with sea level fluctuctions, several waves of immigration must be postulated. The climatic oscillations may even have caused partial extinctions between these immigrational phases. It is almost impossible to reconstruct the faunal movement without a large set of densely and well dated localities. The fauna of small mammals from Yarimburgaz Cave is biogeographically very important since it is almost the only fauna in the region from this time period. Together with other localities to be discovered in the future, it will significantly contribute to an improved biogeographical recornstruction.

\section{Acknowledgements}

We thank Clark Howell for providing the material and his intensive interest in this study. One of the authors (W.S.) is supported by the BMFT through the Hanns-Seidel-Stiftung e.V. (München, Germany). Dr. M. SANDER kindly improved the English version of this paper.

\section{Literature}

Chaline, J. (1972): Les rongeurs du Pléistocène moyen et supérieur de France (Systematique-Biostratigraphie-Paléoclimatologie). - 1-410, 72 Abb., 187 Tab., 17 Taf.; CNRS, Cahier de Paléontologie: Paris.

Farrand, W. R. (1989): Geological observations at Yarimburgaz Cave. pp 15-20. - In Howell, C. \& Arsebuk, G. (1989): Yarimburgaz Cave, Report on investigations and corrent status of researches in the cave of Yarimburgaz (Marmara, Turkey) 1989 Field season. - 1-75 + VIII, 22 Abb., 36 Tab., 37 Taf.; Committee on Research and Exploration, National Geographic Society: Washington D.C..

- (1990): Geochronology of Yarimburgaz Cave, Turkey - in Bermudee de Castro, J. M. \& Arsuaga \& Corbonell, J. L. (eds.): Human Evolution in Europe and the Atapuerca evidence. - Burgos: Junta de Castilla y Leòn.

Felten, H., Spitzernberger, F. \& Storch, G. (1971): Zur Kleinsäugerfauna des Bey-Gebirges, SW-Anatolien. - Natur und Museum, 101 (1): 21-25,5 Abb.; Frankfurt am Main

HeINRICH, W. D. (1982): Zur Evolution und Biostratigraphie von Arvicola (Mammalia: Rodentia) im Pleistozän Europas. - Z. geol. Wiss., 10 (6): 683-735, 26 Abb., 3 Tab.; Berlin.

- (1983): Skelettreste von Lepus euroaeus Pallas, 1778 (Lagomorpha, Mammalia) aus den fossilen Tierbautensystem von Pisede bei Malchin. - Eisz. Z. Humboldt-Univ. Berlin, Math.-Nat. R., 32 (6): 713117, 2 Tab., 1 Taf.; Berlin.

- (1987): Neue Ergebnisse zur Evolution und Biostratigraphie von Arvicola (Mammalia: Rodentia) im Quartär Europas. - Z. geol. Wiss., 15 (3): 389-406, 9 Abb.; Berlin.

- (1990): Nachweis von Lagurus lagurus (PALlas, 1773) für das Pleistozän von Neumark-Nord, Kreis Merseburg. - Veröff. Landesmus. Vorgesch. Halle, 43: 4 Abb., 1 Tab.; Halle.

Heller, F. (1930): Eine Forest-Bed-Fauna aus der Sackdillinger Höhle (Oberpfalz). - N. Jb. Min., Geol. u. Paläont., B, Beil. Bd., 63: 247-298, 36 Abb., Taf. XVXVIII; Stuttgart.

Heller, F., Brunnacker, K., Freund, G., Groiss, J. T., Jànossy, D., Schoch, W., Schweingruber, F. Stadie, C. \& Streit, R. (1983): Die Höhlenruine Hunas bei Hartmannshof (Landkreis Nürnberger Land). Eine paläontologische und urgeschichtliche Fundstelle 
aus dem Spät-Riß. - Quartär-Bibliothek, 4: 1-407, 62 Abb., 12 Taf.; Bonn: Röhrscheid.

Hosey, G. R. (1982): The Bosporus landbridge and mammal distributions in Asia Minor and the Balkans. - Säugetierkundl. Mitt., 30: 53-62, 5 Abb., 1 Tab., München.

Howell, C. \& Arsebruk, G. (1988): Yarimburgaz Cave (1988): Report on investigations in the cave of Yarimburgaz (Marmara, Turkey) 1988 Field season. 1-99, 17 Abb., 22 Taf., 9 Taf.; Committee on Research and Exploration, National Geographic Society: Washington D.C.

- (1989): Yarimburgaz Cave, Report on investigations and current status of researches in the cave of Yarimburgaz (Marmara, Turkey) 1989 Field season. 1-75 + VIII, 22 Abb., 36 Tab., 37 Taf.; Committee on Research and Exploration, National Geographic Society: Washingthon D.C.

Janossy, D. (1962): Vorläufige Mitteilung über die mittelpleistozäne Vertebratenfauna der Tarkö-Felsnische (NO-Ungarn, Bükk-Gebirge). - Ann. Hist.Natur. Mus. Nat. Hungarici, 54: 155-176, 2 Abb., 2 Abb., 2 Taf.; Budapest.

Koenigswald, W. v. (1973): Veränderungen in der Kleinsäugerfauna von Mitteleuropa zwischen Cromer und Eem (Pleistozän). - Eiszeitalter und Gegenwart, 23/24: 159-167, 2 Abb.; Öhringen.

- (1989): Preliminary remarks on the small mammals from Yarimburgaz Cave (Marmara, Turkey). Appendix 1. - in Howell, C. \& AREBUK, G.: Yarimburgaz Cave (1988) - Report on investigations in the cave of Yarimburgaz (Marmara, Turkey) 1988 Field season. - 1-99, 17 Abb., 22 Taf., 9 Taf.; Committee on Research and Exploration, National Geographic Society; Washington D.C.

- (1992): Various aspects of migrations in terrestrial mammals in relation to Pleistocene faunas of Central Europe. pp. 39-47 - In Koenigswald W. v. \& Werdelin L. (eds.): Mammalian Migration and Dispersal Events in the European Quaternary. - Courier Forsch.-Inst. Senckenberg 153; Frankfurt a.M..

- (1995): Mammal Traverse. Quaternary vertebrate faunas in Central Europe. - In SCHIRMER, W.: Quaternary field trips in Central Europe. vol 2: 707-746; München (F. Pfeil).

Markova, A. K. (1990): Pleistocene microtheriofauna of the European part of the USSR. - Int. Symp. Evol. Phyl. Biostr. Arvicolids, 313-338, 19 Abb.; Prag.

- (1992): Influence of palaeoclimatic changes in the Middle and Late Pleistocene onthe composition of small mammal faunas: data from Eastern Europe. Courier Forsch.-Inst. Senbenberg, 153: 93-100, 3 Abb.; Frankfurt a.M..

Montuire, S., Sen, S. \& Michaux, J. (1994): The Middle Pleistocene mammalian fauna from Emirkaya-2, Central Anatolia (Turkey); systematics and paleoenvironment. - N. Jb. Geol. Paläont. Abh. 193: 107 bis 144, 56 figs.; Stuttgart.
Niethammwe, J. \& Krapp, F. (ed.) (1978): Handbuch der Säugetiere Europas. Band 1: Rodentia I (Sciuridae, Castoridae, Gliridae, Muridae). - 1/I: 1-476, 85 Abb., 105 Tab.; Wiesbaden: Akad. Verlagsgesellschaft.

- (ed.) (1982): Handbuch der Säugetiere Europas. Band 2/I: Rodentia II (Cricetidae, Arvicolidae, Zapodidae, Spalacidae, Hystricidae, Campromyidae). - 2/I: 1-649, 207 Abb., 169 Tab.; Wiesbaden: Akad. Verlagsgesellschaft.

- (ed.) (1990): Handbuch der Säugetiere Europas. Band 3/I: Insectivora - Primates. - 3/I: 1-523, 141 Abb., 133 Tab.; Wiesbaden: AULA-Verlag.

ROETTGER, U. (1987): Schmelzbandbreiten an Molaren von Schermäusen (Arvicola LACEPEDE, 1799). - Bonn zool. Beitr., 38: 95-105, 7 Abb.; Bonn.

SANTEL, W. (in press): Die mittelpleistozänen Insectivora, Chiroptera, Rodentia und Lagomorpha (Mammalia) aus der Yarimburgaz-Höhle, westlich von Istanbul (Türkisch Thrazien). - Palaeontographica; Bonn.

Stiner, M. C., ArsebüK, G. \& Howell, F. C. (1996): Cave Bears and Paleolithic Artifacts in Yarimburgaz Cave, Turkey: Dissecting a Palimpsest. - Geoarchaeology, 11 (4): 279-327, 14 fig., 8 tab., 2 app.

- Achyuthan, H., Arsebük, G., Howell, F. C., Josepitson, S. C., Juell, K. E., Pigati, J. \& Quade, J. (1998): Reconstructing cave bear paleoecology from skeletons: a cross-disciplinary study of middle Pleistocene bears from Yarimburgaz Cave, Turkey. - Paleobiology 24 (1): 74-98, 12 fig., 8 tab.

SтоrсH, G. (1975): Eine mittelpleistozäne Nager-Fauna von der Insel Chios, Ägäis. - Senckenbergiana biol., 56 (4/6): 165-189, 49 Abb.; Frankfurt a.M.

Sutcliffe, A. J. \& Kowalski, K. (1976): Pleistocene rodents of the British Isles. - Bull. Br. Mus. nat. Hist. (Geol.), 27 (2): 31-147, 31 Abb., 13 Taf.; London.

TChernov, E. (1968): Succession of redent faunas during the Upper Pleistocene of Israel. (Morphologie, Taxonomie und Systematik der Nagetierfauna in Israel während des jüngeren Pleistozäns.) - Mammalia depicta: 1-152, 130 Abb., 40 Tab.; Hamburg-Berlin.

- (1994): New comments on the biostratigraphy of the middle and Upper Pleistocene of the southern Levante. 333-350 - In BAR-YOSEF, O. \& KRA, R.S. (eds): Late Quaternary Chronology and Paleoclimates of the eastern Mediterranean. - Radiocarbon: Dept. of Geosciences, University of Arizona.

Tobien, H. (1972): Citellus (Rodentia) und Lagomorpha aus den älteren Aufsammlungen an der pleistozänen Lokalität Stránská Skála bei Brno (CSSR). - Studia Musei Moraviae Anthropos, 20 (12): 137-147, 8 Abb., 3 Tab., 1 Taf; Brno.

Vohralik, V. (1991): A record of the mole Talpa levantis (Mammalia: Insectivora) in Bulgaria and the distribution of the species in the Balkan. - Acta Univ. Carolinae Biol. 35: 119-127, 3 Abb., 2 Tab.; Prag.

Manuskript eingegangen: am 26. Juni 1997 